\title{
The experience of rural families in the face of cancer
}

\author{
A experiência de famílias rurais frente ao adoecimento por câncer \\ La experiencia de las familias campesinas con el padecimiento del cáncer
}

\begin{abstract}
Nara Marilene Oliveira Girardon-Perlini', Margareth Ângelo'
' Universidade de São Paulo, School of Nursing, Postgraduate Program in Nursing. São Paulo, Brazil.

How to cite this article:

Girardon-Perlini NMO, Ângelo M. The experience of rural families in the face of cancer.

Rev Bras Enferm [Internet]. 2017;70(3):550-7. DOI: http://dx.doi.org/10.1590/0034-7167-2016-0367

Submission: 07-13-2016 Approval: 12-02-2016

\section{ABSTRACT}

Objective: To understand the meanings of cancer within the experience of rural families and how such meanings influence family dynamics. Method: Qualitative study guided by Symbolic Interactionism as a theoretical framework and Grounded Theory as a methodological framework. Six rural families (18 participants) undergoing the experience of having a relative with cancer participated in the interview. Results: Constant comparative analysis of data allowed the elaboration of an explanatory substantive theory, defined by the main category Caregiving to support the family world, which represents the family's symbolic actions and strategies to reconcile care for the patient and care for family life. Final considerations: Throughout the experience, rural families seek to preserve the interconnected symbolic elements that provide support for the family world: family unit, land, work and care.

Descriptors: Family; Rural Population; Neoplasia; Care; Nursing.
\end{abstract}

\section{RESUMO}

Objetivo: Compreender os significados do câncer presentes na experiência de famílias rurais e como esses significados influenciam a dinâmica familiar. Método: Estudo qualitativo orientado pelo Interacionismo Simbólico como referencial teórico e pela Teoria Fundamentada nos Dados como referencial metodológico. Participaram, por meio de entrevista, seis famílias rurais (18 participantes) que estavam vivendo a experiência de ter um familiar com câncer. Resultados: A análise comparativa constante dos dados permitiu a elaboração de uma teoria substantiva explicativa da experiência, definida pela categoria central Cuidando para manter o mundo da família amparado, que representa as ações e estratégias simbólicas da família visando a conciliar o cuidado do familiar doente e o cuidado da vida familiar. Considerações finais: Ao longo da experiência, a família rural procura preservar os elementos simbólicos que, conectados, constituem o amparo do mundo da família: a unidade familiar, a terra, o trabalho e o cuidado.

Descritores: Família; População Rural; Neoplasias; Cuidado; Enfermagem.

\section{RESUMEN}

Objetivo: Entender los significados del padecimiento por cáncer en la experiencia de las familias campesinas, y cómo influyen en el entorno familiar. Método: Estudio cualitativo con base teórica en el Interaccionismo Simbólico y metodológica en la Teoría Fundamentada en los Datos. Se entrevistaron a seis familias campesinas (18 participantes) que pasaban por la experiencia de tener un familiar con cáncer. Resultados: El análisis comparativo constante de los datos posibilitó la elaboración de una teoría explicativa de la experiencia, con la categoría Cuidando para que se mantenga sostenido el mundo de la familia, que representa las acciones y estrategias simbólicas de la familia con el fin de conciliar el cuidado del familiar enfermo con el cuidado de la vida familiar. Consideraciones finales: Durante la experiencia, la familia campesina intenta preservar los elementos simbólicos que interconectados constituyen el sostenimiento del mundo de la familia: la unidad familiar, la tierra, el trabajo y el cuidado.

Descriptores: Familia; Población Campesina; Neoplasias; Cuidado; Enfermería. 


\section{INTRODUCTION}

Illness is one of the events in the development of family life that interfere with homeostasis, destabilize family dynamics and cause suffering among its members ${ }^{(1-2)}$. Because family is an integrated system of relationships, its characteristics influence the way members organize and reorganize themselves to meet new demands and reconcile their needs and the wellbeing of the family unit ${ }^{(1)}$.

Family dynamics relates to family living, i.e., to the way individuals interact and bond with one another in everyday life, allowing family life to function in a harmonious way ${ }^{(3)}$. This dimension includes the instrumental domain of daily life activities and the expressive or affective domain, related to the roles played by each member and to problem-solving ${ }^{(1)}$. It involves relationships of collaboration, exchange, power and conflict among family members, permeated by openness to communication, affection and cohesion of the family group ${ }^{(1,3)}$.

In order to access family dynamics, it is necessary to understand the systemic interactional patterns developed in the face of events that generate problems, since these correspond to the behavioral mode with which the family group responds to everyday events over time ${ }^{(1)}$.

Within this perspective, cancer is an event that brings about important changes in family functioning, whether through the evolution of the disease, physical and psychological repercussions, perception of the finitude of life, or the myths and fantasies surrounding the patient and his or her treatment ${ }^{(4)}$. Issues related to cancer in the family have been widely explored in the literature ${ }^{(5-7)}$. One of the findings of such studies relates to the fear involved in developing cancer, present in the different stages of the experience, but not always explicit and shared by family members ${ }^{(4,8-9)}$.

Fear of cancer is associated with the symbolic context of uncertainty, pain and suffering related, among other aspects, to the historical-social construction of the meanings of the disease, which are associated with pain, death, guilt, fear and social stigmatization ${ }^{(10)}$. In addition, the media discourse, the high incidence, the psychosocial repercussions and the uncertainties regarding etiology and treatment endow cancer with a symbolic value, as "the greatest fears and also the greatest evils" are projected on it ${ }^{(10-12)}$.

In this sense, the fear of diagnosis, treatment, relapse, disease evolution and death ${ }^{(4,13-15)}$ is viewed as intrinsic to the process of having cancer, although the meaning attributed to that feeling and the way it interferes in family dynamics are not yet fully understood.

It is also observed that most existing studies focus on the reality of residents of urban settings, although demographic data indicate that approximately half the world population lives in rural areas ${ }^{(16)}$. In Brazil, $18.7 \%$ of the population is characterized as rural by the Brazilian Institute of Geography and Statistics (IBGE) ${ }^{(17)}$.

In this sense, a gap is identified in the specialized literature related to cancer fears present in the experience of rural families. Considering the need to expand knowledge on rural family life and understand how the meanings attributed to fear of cancer influence the pattern of family functioning, this investigation takes a closer look at the experience of such families. Therefore, this paper aims to understand the meanings of cancer in the experience of rural families and how such meanings influence family dynamics.

\section{METHOD}

\section{Ethical aspects}

The research project was analyzed and approved by the Research Ethics Committee of the Nursing School of the University of São Paulo (CEP/EEUSP). Participants signed the informed consent term after being informed of the objectives, research methodology and rights set forth in Resolution 196/96 in effect at the time. In the study, the families are identified with the letter $\mathrm{F}$ followed by the cardinal number corresponding to the sequence of interviews.

\section{Type of study and theoretical and methodological frameworks}

This is a qualitative investigation guided by Symbolic Interactionism as a theoretical framework ${ }^{(18)}$. The methodological framework underpinning the study is Grounded Theory (GT), which allows theorization of human behavior and interaction based on the conceptual category resulting from data and related concepts $^{(19)}$.

\section{Methodological procedures}

\section{Study setting}

The setting from which the study sample was drawn was a specialized oncology service, a reference point for cities in the northwestern region of the state of Rio Grande do Sul: Centro de Alta Complexidade Oncológica (CACON - Center for High Oncological Complexity), which operates inside Hospital de Caridade de ljuí ( $\mathrm{HCl}$ - ljuí Charity Hospital) in the city of Ijuí/RS.

\section{Data source}

The study participants were defined by theoretical sampling, with six rural families being interviewed, totaling 18 people and three sample groups. As an inclusion criterion it was defined that participants should be over 18 years of age and aware of the medical diagnosis, and that at least two adults in the family should be present at the interview. One of them could be the actual patient. The choice of which family members would participate in the interview was taken by the family. More than one contact was made with two of the families.

\section{Data collection and organization}

The strategy used for data collection, carried out between 2007 and 2008, was plain observation and interviews. The behavior and interaction of family members and patients during the hospital stay were observed in different sectors of the oncology service. The observed data were recorded in a field log and helped guide the interview.

This consisted of a form with socio-demographic data of the family and patient, the family genogram ${ }^{(1)}$ and questions 
about the family experience, starting with: What has this period of illness been like for the family?

According to the content of the answers and the orientation of the research, other questions were formulated, with the inclusion of circular $^{(1)}$ questions during the interview. Circular questions allowed the identification of differences between family members regarding relationships, ideas, beliefs, thoughts regarding the disease and the future, besides providing an account of the family life history, and helped to understand the evolution of the family system over time. The interviews were carried out according to the availability of the families: two in the hospitalization unit, two in the oncology outpatient clinic and two in the family home.

\section{Data analysis}

Data analysis followed the Constant Comparative Method of Grounded Theory, composed of four stages: comparing incidents applicable to each category, integrating the categories and their properties, delimiting the theory and writing the theory ${ }^{(19)}$. From the proposed analysis process, 11 categories were organized: Belonging to a rural world, which presents the life context of the participants and affords a closer look at aspects of rural family life; Perceiving threat to the world; Having the world invaded by cancer and Feeling helpless, which represent the perceptions and definitions of the family regarding the illness; Seeking to recover security; Mobilizing family resources and Feeling supported, referring to strategies and actions undertaken in the course of the experience; Interacting with a different and urban reality; Constructing a new way of functioning and Accepting the facts, which present the consequences of the actions undertaken; and Reorganizing the family world, which provides a glimpse of the continuity of family life. These interrelated and interacting categories support the central category, Caregiving to support the family world, which affords an understanding of the dynamics of the rural family in the course of experiencing cancer and nominates the theoretical model.

The validation of the theoretical model was performed by participating and non-participating families. In the description of results, the categories are capitalized and in italics.

\section{RESULTS}

Among the six participating families, the interviews involved five patients, four spouses, two daughters-in-law, a sister, three children, a brother-in-law, a mother-in-law and a godmother. All families owned the land they farmed, and four were also involved in dairy production. The family income - on which two people depended on average - ranged from less than one Brazilian minimum wage to five minimum wages. The distance between the family households and CACON ranged from four to 235 kilometers. The age of patients ranged from 37 to 67 years, with a mean age of 55 years. There were three men and three women. Diagnostic time ranged from two to 72 months, with a mean of 25 months.

The analysis allowed the development of a substantive grounded theory, affording comprehension of the dynamics of rural families that experience the onset of cancer in one of their members. The actions of the family during the illness process reveal the nature of the meanings of cancer and how they influence the functioning of families.

The categories identified and the theoretical interrelationships elaborated relate to the continuous and successive family definitions, decisions and actions to provide care for the family world and support it, thus representing the symbolic meaning of this experience for the family. The way in which the categories interact and integrate enabled the identification of the main category, called "Caregiving to support the family world," which helped to grasp the meaning of the movement undertaken by the rural family throughout the experience of illness.

The connection of the main category and the other categories generated enabled the construction of the theoretical model (Figure 1) that represents the trajectory and dynamics of the rural family in the course of the experience. The theoretical model makes explicit the concepts and their properties in a process that evidences the movement of the rural family over time, emphasizing the context, the conditions, the strategies and the defining consequences of the experience.

Caregiving to support the family world represents the family's symbolic actions and strategies to reconcile care for the patient and care for family life, thus preserving the interconnected elements that constitute the rural family world.

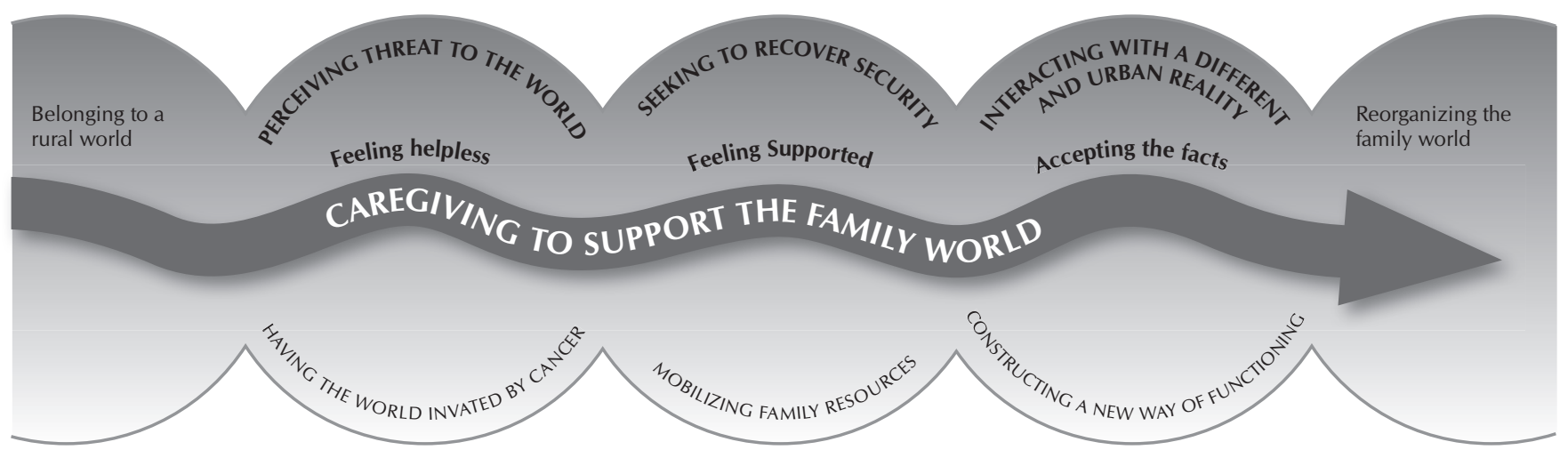

Figure 1 - Diagram representing the theoretical model Caregiving to support the family world 
Belonging to a rural world makes explicit the context in which the family experience occurs. It is in the perspective of this context - expressed by a set of meanings, values and beliefs, shared by the people of that society and generating a particular culture - that the family interacts, acts and assigns meaning to the experience of having a family member diagnosed with cancer.

In this interactional process, each family member interacts, bringing to the present the meanings they give to social objects, past experiences, reference groups, beliefs, and future perspectives. These meanings derive from the social interaction and constant socialization process of each family member and of the members among themselves. Thus, it is with reference to those elements that the rural family interprets, defines and decides what to do in the situation to solve the problems arising from the illness experienced in the present.

We had a plot, we cultivated and harvested everything in the plot, and we owned the land. We have everything that proves that the land was ours. (F1 - patient)

I have children who really wanted me to leave. They are well off in life. I wouldn't have to work, but I was raised outdoors. [...] If I went to an apartment, I wouldn't last long. I'm used to the work, to being free, to tending the livestock... Here I live where I want to be! [...] I knew that if I went to an apartment, it wouldn't be my own space. (F5 - husband)

Perceiving threat to the world is the causal condition of the experience, derived from the perception of the family's organic changes stemming from the suspicion of the diagnosis of cancer. The perception of threat mobilizes the family to interact with the social objects, identifying the symbolic elements present in the situation; and, in a concealed mental activity, to make indications to themselves, to assign meanings, to interpret what they are living and to define reality.

It started with coughing fits. At first, he would take tranquilizers and calm down, and we would call. Afterwards, it was not the same and when we realized there was no other way, we took him to the doctor to see what the problem was. (F3 - brother-in-law)

I sensed it was not good. But I would tell him and... Here in the country we resist to the last... He said to wait, that he would get better. And now he is like this... All because of putting it off... We resist to the very last (F4 - wife)

The consequence of this symbolic experience, associated with the confirmed diagnosis, leads the rural family to initially define the experience as Having the world invaded by cancer.

For him [referring to the son] it was an awful shock, because before I could work, help, and now he has to do everything alone, firewood, pasture, corn, field, cattle... (F2 - patient)

She felt... I don't know how she felt. Remember? Once, about two years ago, she bought chocolate and gave it to each of our children (cries). She said she didn't know if she would make it to the following year. So, her reasoning... It was enough to think what she said... That was during Easter. (F6 - husband)

In the sequence of the experience, Feeling helpless is a consequence of the symbolic interaction of the family with this definition and results in experiencing fears and concerns related to the patient and the family world. The family members feel helpless and in a hostile environment when they feel unprotected, when they recognize their difficulties, when they deal with their own ignorance about the disease and/or face uncertainties about the future.

What's it going to be like for this woman to go to such a big hospital?! (F5 - husband)

He said: I'm going to live here with you! I'll give you the land and you take care of me. (F3 - sister)

We have nothing to live on, we have to put up with it, make do, because, like someone with a salary, he has. We don't. We have to know how to control everything, cent by cent. (F1 - husband)

Caregiving to support the family world, at the beginning of the experience, comprises the symbolic strategies the family needs to implement to adjust to the threat posed by cancer to family life. At that point, the family directs caregiving actions to solve the problem of the sick relative and relieve the sense of helplessness.

Seeking to regain security is a consequence of the initial feelings experienced by the family and, at the same time, a causal condition of the rural family's action in the face of the threat of cancer, characterized by its movement toward support resources to manage the disease and family life. Reflecting on possible alternatives, the family decides to act, going out in search of specialized help, spending the resources of the land, taking care of the family unit, seeking an explanation for the disease and accessing health services.

The first thing we did was to seek medical help. The first thing is the doctor. And the public health system, because we've never had money. To this day we use SUS (Brazilian Unified Health System) (F1 - husband)

Doctor B. and Doctor C. were private... They did not provide care through SUS. So we paid to speed things up. We paid, we spent quite a lot, but it's to live... (F3 - brother-in-law)

Alongside this set of initiatives, the family also implements strategies of the relational domain, Mobilizing family resources to increase its potential to solve problems. The relational forces of the family are evidenced in the family feeling able to care, establishing connections, talking about the illness and accepting help.

The corn I planted this year is there. A neighbor will harvest it for me. I cannot leave this place. (F4 - patient)

Our daughter who lives in Goiás is moving back. She's coming because of us! They left everything behind because of us. (F1- patient) 
(Researcher: - What do you think of that decision?) - Her decision was one of the best things possible, because she left everything, her things, her house, she left everything to come and take care of us [...]. (F1 - husband)

Therefore, these two concepts, Seeking to regain security and Mobilizing family resources, allude to the interactional meaning resulting from the alignment of the individual and relational actions of members, who mobilize the family system to act cooperatively in solving the problem.

They refer to the creation of a relational context that enables people to put themselves in another's place and, through symbolic communication, to capture his or her perspective, aligning their actions with the person's actions and then acting cooperatively, coordinating strategies that help meet their current needs.

The successful coordination of such strategies influences the family to redefine the situation and assign a new meaning to the experience, feeling supported. Feeling supported represents, therefore, the family's feeling regarding the redefinition of the present. This feeling is a consequence of how the rural family interprets the relational and interpersonal contexts experienced in the family unit and in the setting of health services with professionals. The feeling of support comes from the perception of being protected by the family, feeling supported by the community and feeling welcomed in the health services.

When I heard about it, I said: "I'll accompany you all the way there. I'll accompany you to ljuí, wherever you go, if you need to go to São Paulo, I'll go with you. I am your companion... (F5 - husband)

It was hard. But then, with the help of neighbors, everyone helped, lent a hand. They would come round when she was sick, the godmother would come to help, to do the household chores. They were always doing things for me too. They helped to distract us and everything. (F6 - husband)

At this point of the experience, family strategies evidence definitions collectively constructed by the people involved (patient, relatives, neighbors, community members). Thus, Caregiving to support the family world reveals family functioning conditioned by the interactional ability to take on the role of the other, by the alignment of individual actions and by cooperation in solving problems.

Interacting with a different and urban reality is a consequence of the need to manage the patient's situation, which extends the scope of the experience, evidenced by the need to interact in the rural context and also in the urban context, where the therapeutic resources are located.

The worst thing is having to stay in hospital. It's tough in hospital because we don't live here. It's tough having to provide care day and night, sleep on the floor, chair or anywhere. That is what's really hard. (F2 - daughter-in-law)

In situations of illness, with the patient, you learn every day. That is what's happening now. You observe, listen and learn as they explain. So you know, because I've never heard of anyone unable to deal with the situation of a sick person. (F3 - sister)
Interacting in an expanded context imposes on the family the need to redefine a new reality, both geographic and of possibilities of action and interaction; and to establish a new course of action, Constructing a new way of functioning, to ensure the care of the patient, the functioning and support of the family as a whole. The family acts by adjusting to the conditions of the illness, to the needs of the patient, to the needs of the family, modifying its way of working and assuming the task of caring for the patient.

He used to say he didn't like yogurt, but he started liking it. Yogurt was soft and fresh, and he used to eat a lot of it. He ate it with a small spoon, very slowly, despite the catheter. (F3 - sister)

I have to wake up earlier to do everything because she can't help. I wake up at 5 in the morning. I light the fire, put the beans on and go tend the crops. Then I come back at midday... This year I had to lease out the land because I couldn't farm it anymore. At home, I had to look after her. And I had no help... (F1 - husband)

The definitions made by the family regarding the situation experienced in the present establish their line of thought concerning future actions. In the course of the experience, the family continually carries out a mental action constructed by its interaction with the situation of the disease, with the contexts of treatment and care, from which emerge beliefs and definitions about the process of illness as part of the life cycle and the meaning of life and death.

Such mental action, called Accepting the facts - which highlights beliefs and thoughts previously consolidated in the family and others generated by the new situation - is the condition that enables members to incorporate the experience as an event inherent to the life cycle and achieve family goals. Accepting the facts is a consequence of the interaction with the self of each family member, resulting in the interpretation of the interactions and events that make up the experience of the rural family throughout their relative's period of illness.

I believe I have to wait and see what's going to happen. I shouldn't think ahead. It might take a long time or it might be quick. I might get worse, but I might also get better, be cured, forget all this, but the world is as it is, we just have to live and I believe that's more or less it... (F2 - patient)

Whatever our fate is, we have to live it out, nobody can do it for us. Therefore, what is ours no one gives and no one takes away. God sends no messages and does not warn anyone. (F1 - patient)

With the evolution of the experience, and as the family expands contexts and resources to manage and define it, Caregiving to support the family world shows family actions and thought strategies that enable it to continue caring for the patient, to adjust to the reality of the limits of treatment and life, and to ensure the preservation of the family unit.

In this sense, depending on the course of the disease and its impact on family life, Reorganizing the family world is a 
strategy that allows the family to continue the experience, either by learning to live with cancer and its limits or by learning to start over in the face of the absence of a family member.

I am here alone now. I'm rather lost. It's worse at night. There's no one to talk to. So then you miss the person, start brooding... (F1 - husband)

What's hard now is work, her connection with the chores. She thinks she has to do this, do that. She has to get those things off her mind. Why worry so much about chores? (F6 - son)

I had been a widower for five years, she had been a widow for seven. I used to live alone in a big house... I needed to find someone, because we... It's a bad feeling, living alone. When we met... I felt like I was seeing my former wife! I couldn't believe it! (F5 - husband)

Although cancer has a major impact on the life of the rural family, who mobilizes internal and external resources for its care, fear and the threat of cancer are defined by it in a systemic perspective. As shown in the interaction of the categories, Caregiving to support the family world evidences the persistent movement of family care throughout the experience to preserve the symbolic elements that constitute the support of the family's world: family unit, land, work and care. Thus, the experience of the rural family in the face of cancer is a process that covers every dimension of family life and, consequently, moves the family's world, albeit delimited to the period of illness. It is as if the whole family life cycle could be contained in this small cross section.

\section{DISCUSSION}

The model herein presented derives from the experience of the rural family in the face of one of its members being affected by cancer, and, based on the perspective of Symbolic Interactionism, portrays the family experience as a dynamic and systemic process in which all members play a continuous and active role, which complements the model developed in relation to the experience of illness by presenting an element that tries to explain how the family functions in the context of illness ${ }^{(20)}$.

With the support of the family interactionist construct ${ }^{(21)}$, this paper defends the idea that the way the family acts in the face of illness results from a symbolic interaction shared among the family members and others, in which the interpretation and definition of the situation leads to a common perspective, with the alignment of individual actions so that all act cooperatively to solve the problem.

This assertion can be observed in the group cohesion that exists in most rural communities and in social movements in the countryside. The decisive element for people to come together in defense of a given cause is symbolic collective action, which promotes the individual alignment of actions and cooperative action ${ }^{(22)}$.

The meaning present in these actions of cooperative and reciprocal social interaction among rural families is to promote strategies that allow the family to obtain and remain on the land and to develop their space and working resources ${ }^{(23)}$, thus enabling the support of the family world. In this perspective, it can be inferred that care resulting from the capacity to put oneself in the other's place constitutes the protective shell of families in the rural community.

The Theoretical Model that represents the experience of the rural family makes it possible to understand, from the context of rural life, how the family functions during the period of the cancer treatment in its quest to preserve the integrity, stability and homeostasis of the system ${ }^{(3)}$. The need for the family to distance itself from its environment to deal with the disease leads to a scenario which reveals clearly the difficulties and challenges related to distance and displacement, to the lack of infrastructure and resources of local health services to solve problems. Although previous studies report common points in the experience of illness between urban and rural families, the aspects related to distance from the site of treatment are the main differences ${ }^{(24)}$.

The complexity of the situation involving families in the face of one of their members being affected by cancer confirms what is described in the literature regarding the results of investigations carried out to understand the experience and needs of families living far from treatment centers, which presupposes the existence of similarities in experiences inherent to life in rural areas, regardless of nations ${ }^{(24-25)}$.

In this sense, a literature review that sought to understand the experience and needs of people living in urban and rural areas identified that most studies presented worse results for rural patients, who seemed to have greater needs in the physical and daily life domains. The need to travel for treatment caused many practical, emotional, and financial problems for patients, overburdening them with additional concern about family and professional commitments. While sharing experiences with others who are also away from home has been considered beneficial by some people, most agreed that staying at home was preferable ${ }^{(26)}$. These results are similar to those obtained in this investigation.

The studies on the subject describe the innumerable adverse conditions experienced by families who need to move from rural to urban areas for cancer treatment, suggesting that this context of vulnerability to which the family is submitted produces a feeling of helplessness. However, as a symbolic meaning of the interactional process in the situation of illness, this concept is not clearly evidenced in the literature.

The idea presented allows an understating of the feeling of helplessness as being related to a family perspective that is much more complex than the destabilization of the family caused by changes in the organization of family life due to the need to travel for treatment and the development of specific skills to deal with the disease.

\section{Limitations of the study}

The limitations of the study relate to the amount of participating families and the fact that they are families from small rural properties, which restricts the possibility of generalizing the results to this sociocultural contingent. 


\section{Contributions to the area of nursing}

Regarding the implications of the Theoretical Model Caregiving to support the family world for the area of nursing, it is understood that it may contribute to guide the teaching and action of nurses in relation to the family phenomenon, allowing them to come closer to family experiences, understand their fears and, consequently, propose care strategies aligned with the creation of a cooperative relational context aimed at family support.

Within the scope of research, considering that the theoretical models are not self-exhausting, they must be validated and expanded and also experimented in teaching, clinical practice and research. Understanding the problems and dimensions involved in the functioning of rural families in the face of illness in other situations and in other geographical contexts may contribute to the theoretical and practical advancement of family nursing.

\section{FINAL CONSIDERATIONS}

For rural families, the experience of cancer is a situation that compromises the symbolic elements that give meaning to rural life. The disease puts the family at risk as a unit, interferes with the dynamics of family work, increases the demands of care and threatens the land. In such a context, the family, through symbolic collective action, defines the situation and feels helpless as it perceives the threat to its world. Thus, the perception of threat to one of these symbolic elements of the family results in the feeling of helplessness.

The model herein developed represents an advance in knowledge related to family by making explicit how the symbolic elements present in the experience of the rural family in the face of cancer influence family dynamics. Understanding the experience reveals, in the movement of families, elements related to culture, beliefs and values that give meaning to family life in the rural context. It is perceived that, in the rural family experience, having one its members affected by cancer evidences that the meaning attributed to this disease is threat, and that the prevailing fear is helplessness.

Despite the evident complexity surrounding the family world and its connections and the repercussions caused by illness in the family context, it can be said that the interactionist perspective, used to analyze the family, and Grounded Theory allowed the elaboration of the Theoretical Model, which enables the understanding of family movements as an integrated and harmonious process, aimed at a common goal. The actions developed by each family member in particular and directed towards a specific aspect are part of a broader action whose sense cannot always be perceived and which constitutes the true meaning of action.

\section{REFERENCES}

1. Wright LM, Leahey M. Enfermeiras e famílias: um guia para avaliação e intervenção na família. $5^{a}$ ed. São Paulo: Roca; 2012.

2. Vizzachi BA, Daspett C, Cruz MGS, Horta ALM. A dinâmica familiar diante da doença de Alzheimer em um de seus membros. Rev Esc Enferm USP [Internet]. 2015 [cited 2016 May 29];49(6):933-8. Available from: http://www.scielo.br/pdf/reeusp/v49n6/ pt_0080-6234-reeusp-49-06-0933.pdf

3. Henao AMG. Recuperación crítica de los conceptos de familia, dinámica familiar y sus características. Rev Virt Univ Católica Norte [Internet]. 2012 [cited 2016 May 29];35:326-45. Available from: http://revistavirtual.ucn.edu.co/index.php/RevistaUCN/ article/viewFile/364/679

4. Farinhas GV, Wendling MI, Dellazzana-Zanon LL. Impacto psicológico do diagnóstico de câncer na família: um estudo de caso a partir da percepção do cuidador. Pensando Fam. [Internet]. 2013 [cited 2016 May 29];17(2):11-129. Available from: http://pepsic. bvsalud.org/pdf/penf/v17n2/v17n2a09.pdf

5. Li Q, Loke AY. A literature review on the mutual impact of the spousal caregiver-cancer patients dyads: 'communication', 'reciprocal influence', and 'caregiver-patient congruence'. Eur J Oncol Nurs [Internet]. 2014 [cited 2016 May 29];18(1):58-65. Available from: http://www.ejoncologynursing.com/article/S1462-3889(13)00099-9/pdf

6. Mathias CV, Girardon-Perlini NMO, Mistura C, Jacobi CS, Stamm B. Adoecimento de adultos por câncer e a repercussão na família: uma revisão da literatura. Rev Atenção Saúde [Internet]. 2015 [cited 2016 May 29];13(45):80-6. Available from: http://seer. uscs.edu.br/index.php/revista_ciencias_saude/article/view/2818

7. Laidsaar-Powell R, Butow P, Bu S, Charles C, Gafni A, Fisher A, Juraskova I. Family involvement in cancer treatment decisionmaking: a qualitative study of patient, family, and clinician attitudes and experiences. Patient Educ Couns [Internet]. 2016 [cited 2016 May 29]; in press. Available from: http://www-sciencedirect-com.ez47.periodicos.capes.gov.br/science/article/pii/ S0738399116300350

8. Piolli KC, Medeiros M, Sales CA. Significations of being the caregiver of the companion with cancer: an existential look. Rev Bras Enferm [Internet]. 2016 [cited 2016 May 29];69(1):99-105. Available from: http://www.scielo.br/pdf/reben/v69n1/en_0034-7167-reben-69-01-0110. pdf

9. Grob SE, Nitzsche A, Gloede TD, Ansmann L, Street R, Pfaff H et al. The initial clinical interview can it reduce cancer patients' fear? Support Care Cancer [Internet]. 2015 [cited 2016 May 29];23(4):977-84. Available from: http://link-springer-com.ez47. periodicos.capes.gov.br/article/10.1007/s00520-014-2450-6/fulltext.html 
10. Tavares JSC, Trad LAB. Metáforas e significados do câncer de mama na perspectiva de cinco famílias afetadas. Cad Saúde Pública [Internet]. 2005 [cited 2016 May 29];21(2):426-35. Available from: http://www.scielo.br/pdf/csp/v21n2/09.pdf

11. Beach WA, Easter DW, Good JS, Pigeronc E. Disclosing and responding to cancer "fears" during oncology interviews. Soc Sci Med [Internet]. 2005 [cited 2016 May 29];60(4):893-910. Available from: http://www.sciencedirect.com/science/article/pii/ S0277953604003156

12. Clarke JN, Everest MM. Cancer in the mass print media: fear, uncertainty and the medical model. Soc Sci Med [Internet]. 2006 [cited 2016 May 29];62(10)2591-600. Available from: http://www.sciencedirect.com/science/article/pii/S0277953605006088

13. McCarthy B, Andrews T, Hegarty J. Emotional resistance building: how family members of loved ones undergoing chemotherapy treatment process their fear of emotional collapse. J Adv Nurs [Internet]. 2015 [cited 2016 May 29];71(4):837-48. Available from: http://onlinelibrary-wiley-com.ez47.periodicos.capes.gov.br/doi/10.1111/jan.12549/epdf

14. Dunn LB, Langford DJ, Paul SM, Berman MB, Shumay DM, Kober K, et al. Trajectories of fear of recurrence in women with breast cancer. Support Care Cancer [Internet]. 2015 [cited 2016 May 29]; 23(7):2033-43. Available from: http://link-springer-com.ez47. periodicos.capes.gov.br/article/10.1007/s00520-014-2513-8/fulltext.html

15. Simard S, Thewes B, Humphris G, Dixon M, Hayden C, Mireskandari S, Ozakinci G. Fear of cancer recurrence in adult cancer survivors: a systematic review of quantitative studies. J Cancer Surviv [Internet]. 2013 [cited 2016 May 29];7(3):300-22. Available from: http://link-springer-com.ez47.periodicos.capes.gov.br/article/10.1007/s11764-013-0272-z/fulltext.html

16. Relatório sobre a Situação da População Mundial 2011. Divisão de Informações e Relações Externas do UNFPA. Fundo de População das Nações Unidas[Internet]. 2011 [cited 2016 May 29]. Available from: http://www.un.cv/files/PT-SWOP11-WEB.pdf

17. Brasil. Instituto Brasileiro de Geografia e Estatística (IBGE). Sinopse do Censo demográfico 2010[Internet]. 2011 [cited 2016 May 29]. Available from: http://www.censo2010.ibge.gov.br/sinopse/index.php?dados $=8$

18. Charon JM. Symbolic interacionism: an introduction an interpretation, an integration. 10a ed. Englewood Cliffs: Prentice-Hall, 2009.

19. Glaser B, Strauss A. The discovery of grounded theory. Chicago: Aldine, 1967.

20. Morse MM, Johnson JL. The illness experience: dimensions of suffering. Newbury Park: Sage. 1991.

21. Angelo M. Com a família em tempos difíceis: uma perspectiva de enfermagem. [Tese]. Escola de Enfermagem, Universidade de São Paulo. 1997. 117p.

22. Woortmann K. "Com parente não se neguceia” O campesinato como ordem moral. Anuário Antropológico/87. Brasília: Editora Universitária de Brasília/Tempo Brasileiro, 1990.

23. Severo DO, Da Ros MA. The landless rural workers' movement and National Health System (SUS) social control: perspective of the national collective of health. Saude Soc. 2012; 21(supl.1):177-84.

24. Brazil K, Kaasalainen S, Williams A, Rodriguez C. Comparing the experiences of rural and urban family caregivers of the terminally ill. Rural Remote Health [Internet]. 2013 [cited 2016 May 29];13(1):2250. Available from: http://www.rrh.org.au/publishedarticles/ article_print_2250.pdf

25. Miedema B, Easley JKE, Robinson LM. Comparing urban and rural young adult cancer survivors' experiences: a qualitative study. Rural Remote Health [Internet]. 2013 [cited 2016 May 29];13:2324. Available from: http://www.rrh.org.au/publishedarticles/ article_print_2324.pdf

26. Butow PN, Phillips F, Schweder J, White K, Underhill C, Goldstein D. Psychosocial well-being and supportive care needs of cancer patients living in urban and rural/regional areas: a systematic review. Support Care Cancer [Internet]. 2012 [cited 2016 May 29];20(1):1-22. Available from: http://www.ncbi.nlm.nih.gov/pubmed/21956760 